Um Pouco de História 


\title{
Desafiados por Graciema Pacheco'
}

\author{
Jacira Cabral da Silveira
}

Getúlio Vargas nomeou Graciema Pacheco para a cátedra de Didática da Faculdade de Filosofia da Universidade Federal do Rio Grande do Sul em 1947, que concentrava todos os cursos de licenciatura, inclusive o de Pedagogia, no qual ela já ministrava a disciplina de Psicologia desde 1945. A possibilidade de atuar junto a diferentes cursos fez com que Graciema marcasse a formação e a prática profissional de várias gerações.

"Em certo momento, ela muda minha cabeça como educador", comenta o professor emérito da UFRGS, Luiz Osvaldo Leite, referindo-se às aulas que teve com a docente de 1956 a 1957, quando se licenciou em Filosofia. "Eu venho de uma geração em que as aulas eram expositivas até no curso secundário". Mas Graciema me ensinou o seguinte: ensinar não é só ensinar, existe sempre uma dupla relação. Só há ensinar quando há o aprender", repete as palavras de sua mestra.

Merion Bordas, também professora emérita da Universidade e ex-diretora da Faculdade de Educação (Faced), não só estudou com Graciema como foi convidada por ela para ser uma de suas assistentes na disciplina de Didática. "Era típico dela começar a aula e, lá pelas tantas, dizer 'agora continua minha filha', e a gente tinha que continuar”, recorda. Embora sempre provocassem um frio na barriga, esses momentos desafiadores serviram para que as assistentes intensificassem seus estudos ao prepararem as aulas de didática por noites a fio. "Mas ela fugia do planejamento e tínhamos que inventar na hora", acrescenta.

1 Parte do texto O lugar dos Grandes Mestres, de Jacira Cabral da Silveira, publicado no Jornal da Universidade, publicação da UFRGS. Ano XVI, Número 152, setembro de 2012. Disponível em: < http://www.ufrgs.br/comunicacaosocial/jornaldauniversidade $>$ Acesso em: 10 set. 2012 
Antes mesmo de atuar como catedrática, Graciema já dera aula no Instituto de Educação General Flores da Cunha, onde era responsável pela disciplina de Psicologia, área que estudara durante sua formação na Escola Complementar. Na década de 1920, após concluir o curso Normal, fez um aperfeiçoamento filiado ao movimento de renovação dos conhecimentos em educação. Esse movimento era ligado a um grupo de Jean Piaget, cujas primeiras obras estavam sendo publicadas, causando grande repercussão, sobretudo na psicologia genética. "Fui eu que falei pela primeira vez nele [no Rio Grande do Sul]", disse certa vez Graciema numa entrevista, gabando-se por conseguir as obras do autor suíço através do Instituto Jean-Jacques Rousseau.

$\mathrm{O}$ interesse pela pesquisa em educação foi um dos fatores que impulsionaram Graciema a fundar, em 1954, o Colégio de Aplicação, do qual foi diretora por 28 anos. Um de seus objetivos era transformá-lo num centro de pesquisa para onde levava suas alunas que se destacavam na disciplina didática. "Era uma honra trabalhar com ela no Aplicação", salienta Merion, que lecionou naquela instituição a convite de sua professora. "O Colégio era uma espécie de pós-graduação. Tanto o grupo de alunos como o de professores era diferenciado. Todos os meninos da época vinham de famílias intelectualmente desenvolvidas e os docentes eram muito exigidos”, contextualiza.

"A disciplina do Colégio, sobremodo no trabalho, marcou profundamente a minha atividade, inclusive no curso superior", declara Donaldo Schüler, professor emérito da UFRGS. 'Nós não tínhamos livro didático e os programas de ensino eram construídos dentro de algumas regras estabelecidas com os próprios alunos. Eles eram participantes do seu processo de educação", lembra Donaldo ao relatar a sistemática do trabalho desenvolvido no Aplicação.

Entretanto, contrariando esse perfil inovador quanto às questôes de aprendizado, Graciema tinha comportamentos conversadores, que denotavam sua formação moral católica. $\mathrm{Na}$ avaliação de Leite, esse teria sido o motivo de a professora ter 
saído ilesa do período militar, que vitimou os demais mestres relacionados neste Caderno ${ }^{2}$. "Em termos políticos era mais conservadora, mas foi revolucionária em educação”, reconhece.

Merion também tem exemplos nesse sentido. Ela conta sobre o dia em que Graciema, ao vê-la com um vestido sem mangas e decotado, perguntou-lhe: "Minha filha, quem sabe tu colocas um bolerinho". Muito jovem e bonita, ela apenas sorriu constrangida. "Ela era toda exigente com relação à roupa. A gente tinha que se vestir absolutamente sem charme, feito freira", acrescenta, mas reconhece que esse era o pensamento vigente nas escolas de magistério, e que não era uma ideia exclusiva de sua professora. Até porque: "Dona Graciema tinha coisas muito especiais, ela marcou nossa geração".

2 Caderno JU No 1 , Edição 152 do Jornal da Universidade. Os professores referidos são Gerd Bornheim, Ernani Fiori e Leônidas Xausa. 